\section{Those old familiar edifices}

Fiona Steele

The Great Engineers. Edited by Derek Walker. Academy Editions, 42 Leinster Gardens, London/St Martin's Press, New York: 1987. Pp.288. £35, \$50.

IT was fitting, and indeed encouraging, that the 150th anniversary of the founding of the Royal College of Art (RCA) should have been marked recently by a compelling exhibition devoted to a celebration of engineers and engineering, and by the publication of this book. The thesis embodied in The Great Engineers, a volume of some 20 essays edited and coauthored by Professor Derek Walker, is the perpetual search for excellence which has dominated the lives of Britain's greatest inventors and engineers, and the relationship between art and design, and manufacture and construction.

The familiar names from the past are here - Brunel, Telford, the Stephensons - but Walker has encouraged his contributors to provide very personal perspectives of the lifestyles and achievements of their chosen subjects. Although these engineers attracted wide public attention and renown, there are others, perhaps not so well known, whose contributions were equally significant. So, for example, we have an essay on Sir Joseph Bazalgette, who did so much to improve the health of Londoners through his design and execution of a massive programme of sewer installation in the last century. This is one of the most interesting contributions in the book and is especially timely in view of the present debate over infrastructure renewal, a problem not confined to Britain. It is salutary to learn that throughout his career Bazalgette argued for powers to bring private water companies in London under the control of a single Metropolitan Water Board; and not content with the problems of water supply and sewage disposal, he also sought to improve the total built environment and laid down criteria for planning which are still pertinent today.

Moving into the twentieth century, the legend of excellence is represented by the great modern partnerships, Arup, Samuely, Happold, where engineering and art continue to feed on each other to produce visually exciting, if sometimes controversial, structures. This marriage of minds brought together through design is a recurring message throughout the various contributions.

Not that the book is purely concerned with the 'structural' side of things. Walker has acknowledged the diversity of engineering by commissioning contributions on communications, materials and electronics. Although these provide an interesting balance, they do not offer the excitement and infectious enthusiasm of the rest of the book. The RCA itself is featured in an intriguing, indulgent article on the Duke of Wellington's funeral car, and indeed the whole book is very much an indulgence. But celebrations are a legitimate excuse for some excess, and the book deserves a wider reading and viewing than the engineering fraternity. It is beautifully illustrated, looking at structures in their entirety and in the context of their setting, and then delving into the minutiae of their

\section{Circular reasoning}

Thomas J. Kindt

Regulatory Idiotopes. By Constantin A. Bona. Wiley: 1987. Pp.279. \$59.95, £52.50.

IT Is elementary that injection of an animal with an antigen results in formation of an antibody (AB1). When a genetically matched animal is then injected with $\mathrm{AB} 1$, an anti-antibody (AB2) directed against unique determinants of $A B 1$ is generated. $A B 2$ is generally termed an anti-idiotype.

What happens when $A B 2$ is injected into a third genetically identical animal ceases to be elementary. If, for example, the antigen that induced $\mathrm{AB} 1$ was a hormone, then $\mathrm{AB} 2$ may possibly react with the receptor for that hormone because AB2 contains the 'internal image' of the original antigen. Continuing along the same line of reasoning, $\mathrm{AB} 2$ can be used as a vaccine to generate a response to a harmful pathogen and thereby circumvent the need to expose the subject in order to achieve immunity. Similarly, memory may be carried in the immune system by antibodies that have internal images of previously encountered antigens. All this may sound like an immunologist's fantasy, but most of these manipulations have been carried to successful conclusions and constitute the subject of Constantin Bona's book.

Although the concept of unique determinants on immunoglobins has been in the literature since 1955 , and the word 'idiotype' has been in use since 1963 , only a few early investigators experimented with this tool. It took the ideas embodied in Niels Jerne's network hypothesis of the early 1970 s to elicit broad interest in the possibilities that idiotypy had to offer. The 'idiotope' in the title of this book is the epitope of an idiotype, and the fact that it is modified by 'regulatory' implies that there are other (non-regulatory) idiotopes. In spite of this qualification, Bona satisfactorily develops the general concepts necessary to view idiotypy in proper anatomy. It must have been great fun assembling the pictures and drawings.

There are niggles - duplication in illustrations, a lack of order, too much text in one place, too little in another, nonBritish inventions in a list of British inventions - but these can be tolerated. The book is not easily portable but if taken on a journey readers must be prepared to accommodate the over-the-shoulder attention of their fellow passengers.

Fiona Steele is Head of the Technology Group, Confederation of British Industry, Centre Point, 103 New Oxford Street, London WC1A $I D U, U K$.

perspective. A certain sophistication is assumed on the part of the reader and the introduction would have been better for the distinction used by Oudin to separate antigenic determinants of antibodies into isotype, allotype and idiotype. This information has escaped many modern students of immunology, who tend to view antibodies (B-cell receptors) as products of interacting genes rather than as serological targets.

This monograph takes the reader beyond the basic concept of idiotypy, concentrating throughout on the premise that the idiotope is a central player in the biological drama, a regulatory element with a myriad of possible functions. Although the treatment is not without some bias towards Bona's own considerable contributions to the area, his insights are keen and will help guide the reader confronted with a distillation of over 600 references. It is not possible to digest the entire volume in one sitting, but the chapters and subchapters stand alone quite well and some are entertaining as well as informative. That covering internal images was especially appealing to me. Other chapters are too crammed with examples to make light reading, but will serve as excellent reference material on the subject matter concerned.

The book is the second volume of a series edited by Bona, and will be a worthwhile acquisition for those who have a direct or peripheral interest in the area. Even those who disagree with the concept of regulation by antibodies will find it to be an excellent source of information. For myself, Regulatory Idiotopes will replace an overflowing file of papers on the subject, and will serve as a guide to a field that I have monitored with varying degrees of enthusiasm for many years.

Thomas J. Kindt is Chief of the Laboratory of Immunogenetics, National Institutes of Health, Bethesda, Maryland 20892, USA.

- Erratum. The recently published second edition of The Idea of Prehistory is by Glyn Daniel with two additional chapters by Colin Renfrew. The first edition was by Glyn Daniel, not by Colin Renfrew as suggested (Nature 331, $493 ; 1988)$. 